\title{
Pedagogical Conditions for Forming Professional Subjectivity of Future Physical Education Teachers
}

\author{
Bytsiuk Viktoriia*, Mazin Vasy \\ Classical Private University, 70-b, Zhukovskiy str., Zaporizhzhya, 69002 Ukraine \\ *Corresponding Author: Bytsiuk Viktoriia, Classical Private University, 70-b, Zhukovskiy str., \\ Zaporizhzhya, 69002 Ukraine
}

\begin{abstract}
The authors specify the main points of the term "pedagogical conditions". The study defines pedagogical conditions for forming professional subjectivity of future physical education teachers. These pedagogical conditions are: improvement of the provided subjects' content with thematic modules focused on professional subjectivity forming; creating positive image of professional prospects during foreign study course; reflective ambience forming for awareness of the contradiction between preferable and current status of professional competencies development; encouraging students to represent their personality in extracurricular socially significant activity; implementation of check-out methodology focused on evaluation of professional subjectivity level of future physical education teachers
\end{abstract}

Keywords: Future physical education teachers, pedagogical conditions, subjectivity, forming.

\section{INTRODUCTION}

Among factors set components, that influence health and working ability of younger generation, there is an essential one such as professional and sufficient activity of future physical education teachers. This staff provides assistance for balanced physical development of children and youngsters, their background for well-being fulfilling life.

The start of the program "New Ukrainian school" (Nova ukrayins'ka shkola) is the first stage for transforming physical education teachers' working activity aiming to change day-to-day performance of externally regulated special measures to creative activity with self-fulfillment as the way of personal content objectification during professional engagement and interaction with learners.

Results of physical education teacher's self-fulfillment greatly depend on one's subjectivity level. In our research we define subjectivity as a professional feature that allows a teacher to be a working activity strategic thinker, set and correct its target, be aware of motives, self-planning capability and professional activity evaluation.

Modern science has many examples of teacher's professional subjectivity research, for example, works by O. Bartkiv, Yu. Zhurat, N. Larionova, O. Meshko, S. Pevna, T. Severin, O. Cy`mbal, S. Shexavczova. The authors stress that quality is formed, first of all, due to providing basic professional education.

Furthermore, according to our analysis of the scientific resources each author suggests own way of subjectivity forming. At the same time the studies don't represent at all any conditions of forming this future physical education teachers' feature.

\subsection{Purpose and Objectives}

Taking into consideration all the points that were actualized above, we conducted the investigation with the purpose to justify pedagogical conditions of forming subjectivity as a feature of students in specialty 014 Secondary Education (Physical Education) (Ukraine).

Among the tasks of the current paper there are: analysis of the scientific resources to define the most valuable ideas about forming future teachers' subjectivity; generalization of professional education achievements in framework of authors' approach of forming professional subjectivity of future physical education teachers. 


\subsection{Materials and Methods}

We analyzed up to 100 scientific resources.

\section{RESUltS}

Due to deep and profound investigation scientific works of pedagogical sphere we are able to clarify the meaning of the term "pedagogical conditions". Having generalized definitions that were offered in predecessors' works $[1 ; 7 ; 8]$, we come to the conclusion that pedagogical conditions are specially made circumstances that are necessary and sufficient for forming professional subjectivity of future physical education teachers.

The first circumstance is the improvement of the provided subjects content with thematic modules focused on forming professional subjectivity of future physical education teachers.

On the way to this goal we need to update curriculum subjects' content with certain chapters and subject matters, represented in content modules according to the type of material. The supplements must be focused on forming of different aspects of future physical education teachers' professional subjectivity.

Trustworthy provement of this condition we see in the fact that training of physical education and sport experts has differences in curriculum subjects, terms and conditions of study, duration of vocational training in European universities, and is carried out according to credit-module system of educational process organization. Issues of educational process organization for guidance of physical education and sport experts in framework of module scheme are revealed by many Ukrainian scientists (M. Burenko [1], A. Chornoshtan [8] etc.). Great interest of the scientists, in our opinion, is a sign of this learning effectiveness.

The discussed condition is based on competitive approach in education, which in its turn can be described as a scientifically grounded way of educational process forming with target reference points (competences) and certain content of education.

It is necessary to highlight that competitive approach supposes student's subjectivity rise within educational process, this subjectivity correlates to active learners' participation in gaining knowledge, skills, personal experience and also competence implementation and forming of useful behavior models, which can help to do typical routine activity as well as solve challenging problems on one's own, and even define new reference points of professional activity [4].

Forming this pedagogical condition means introduction of certain complex with specially designed modules for particular subjects in education of students, specialty 014 Secondary Education (Physical Education). Studying cores of these modules are associated with different aspects of professional subjectivity of physical education teacher. We point out that curriculum changes and even more, sphere standards ones are not practical and efficient.

The content of the module must be profound and self-sustained logically designed parts. All of them must have clearly defined educational purpose and objectives, also main terms, skills that are formed during the module; it is necessary to provide measure and evaluation scheme of task performance, activity, student's class attending statistics; offer entry, progress and end-of-course test of student's level.

Each module must be provided with necessary deductive and methodological materials. Also, every module program of the educational subject must be available for learners from the beginning of their education. Contents of the subject must be structured according to complex, integrative and fractional deductive purposes, and student should consider them as a personal significant and predicted result. Besides, set of the modules must represent the whole body in the frames of any curriculum subject [1, c. 77].

It is important to note, that design of the module's content has the background of particular crucial and empirically motivated target educational reference points, which enables to provide high level of order, structure and technological effectiveness of obtaining professional knowledge by learners.

We consider that the content of each these modules must be revealed and represented during lectures, tutorials, classes and independent studies. 
Dealing with the issues of forming professional subjectivity of future physical education teachers, we paid attention to such theoretical subjects as "Introduction to Specialty", "Theory and Methodology of Physical Education", "Pedagogics", "Psychology", and also some of the practical subjects, for example, "Gymnastics and Teaching Methodology", "Track and Field Athletics and Teaching Methodology", "Sports and Teacher-training Improvement", "Outdoor Games" and so on. We believe that exactly these subjects help to create the essential element of the professional education and play catalytic role in forming professional subjectivity of future physical education teachers.

No doubts, that improvement of the provided subjects' content with thematic modules focused on professional subjectivity forming will facilitate overcoming the contradiction between new promising paradigm of professional education (declaring necessity of active subjective role of future physical education teacher in professional activity) and current trend of lack of attention to forms of its implementation in professional training of students, specialty 014 Secondary Education (Physical Education).

In our opinion, the second crucial condition is creating positive image of professional prospects during foreign study course.

It means that students, specialty 014 Secondary Education (Physical Education), are to spend particular part of their study in foreign higher education institution in the framework of semester program of academic mobility or bilateral (dual) degree obtaining program.

Offering and implementing this condition is a form of practical realization and fulfillment of Bologna Process requirements aimed at creating and balancing common European educational space due to arrangement several international programs of students' exchange between Ukrainian and European universities. These programs are available because of European Credits Transfer System (ECTS) operating as a modern approach in educational process [3].

The condition is correlated to activity approach practice (O. Leontiev, S. Rubinshtein), according to the activity approach origin reason for any human's performance is an one's aspiration to embody internalized images in the environment [6].

In the framework of the activity approach practice scientists agree, that in modern education during the study due to imago images implementation we can see process of forming personality, who independently chooses, evaluates, programs and constructs different kinds of activities to satisfy person's needs in both self-development and self-fulfillment.

We believe that the first way to create this condition is to join bilateral (dual) diploma obtaining program.

We share opinion of Ye. Hordiichuk, that bilateral (dual) degree obtaining program means an educational program, which is based on comparison and synchronizing educational content of universities-partners, both parties have an agreement about general duties and responsibilities in such spheres as defining purposes and tasks of the education, curriculum arrangement, educational process organization to get special qualification. There are some key features of dual degree program, for example, they are based on common theoretical background and integrative curriculum implementation. Study in the framework of such programs ends up with common (dual) educational degree obtaining [3].

The second way to create condition 'positive image of professional prospects during foreign study course' is to study according to semester programs of academic mobility. In this case Ukrainian students study the certain courses and subjects that were chosen deliberately and are absent in the curriculum of the host higher education establishment. It is done to broaden and improve gained knowledge, skills and abilities. If a student chooses the subjects that are included in base curriculum, then one will be given a credit for all tests and examinations passed in European higher education establishment. Participants of the international academic mobility program study (have training) in European higher education establishment within fixed terms, and after program finish they obtain relevant documents (for instance, academic references, student's academic record books, appendixes and so on) with results of the study to be noted. 
In our opinion, positive image of professional prospects created during training course in European higher education establishment can encourage students to do well, will be one of the effective incentive actions, and also let promote self-sustained cognitive activity.

We expect that all the provided means will be suitable for intensification of personality's key professional competences, forming skills for self-education and team-work abilities; moreover, they will have positive impact on integration into international professional community. We also believe that this condition forming will lead to significant competitiveness increase of learners at the labor market because of their advanced experience gaining.

The third condition - forming reflective ambience in quasi-professional activity to make students aware of the contradiction between preferable and current status of professional competencies development.

Fulfillment of the condition means triggering students' introspection of process and results of that activity which imitates the professional one.

Necessity of this condition providing is determined by professional and personal development process. In this case the top priority of the process is to cope with and overcome some contradictions between professional activity demands and real students' maturity level in professional environment.

Activity approach is not the only part of the theoretical background for the named condition forming, it is necessary to mention reflective and contextual approaches as well.

According to the reflective approach reflection is an introspection, self-analysis of inner psychological acts and states such as personality structures (values, interests, motives), thinking and also way of perception, making decisions, emotional reaction, behavior stereotypes.

The main idea of the other approach, the contextual one is to gear educational process of students in higher education establishments to conditions of professional activity due to implementation learners' education activity in professional context, filling educational process with elements of professional activity, focusing it on students' self-fulfillment [1, c. 63].

Context-based learning has an activity theory background; according to the theory social experience adoption is performed as a result of conscious, responsible and determined subject's activity. We need to draw attention to performance of gradual phase switch to basic forms of top practice: starting with primary activity of the academic type to quasi-professional activity (business and deductive games), and, later to educational and professional activity (scientific research, practice, training, apprenticeship etc.) [2].

Forming this condition correlates with several methods, which are implied into practical classes and tutorials, educational training and students' scientific research.

Effective practical classes, in our opinion, must combine significant features of physical education class and deliberate forming quasi-professional conflict and non-conflict situations, and a student needs to perform some pedagogical position and pedagogical techniques with possible (if it is necessary) disposition change, representing suitable means and methods of professional activity.

In our research we insist that educational trainings in general secondary education establishments must be focused on students' subjectivity forming. In order to reach this goal we suggest organizing external evaluation of their activity with the following discussion of their performance.

We believe that scientific research must be focused on encouraging reflective behavior models during the research practice. It should be mentioned that the student and their group mates will be objects of the investigation.

At the same time we state that usage of different forms, methods and means of context-based education must combine with traditional methods. Accepting new ways of teaching won't be successful without thoughtful mix with achievements and advantages of traditional methodology techniques.

In the framework of quasi-professional activity in reflective environment we expect personality's professional self-identification to form, students will be ready to their professional roles, values, requirements and regulations. 
We are convinced that forming the named condition will enable to eliminate the contradiction between, on the one hand, necessity of future physical education teachers' willingness to perform their subjectivity in certain pedagogical situations of the educational process and professional activity and, on the other hand, shortage of professional training methods, aimed to form and develop relevant competences.

The next condition is encouraging students to perform their personality in the spare time and extracurricular socially significant activities.

We consider that it is crucial to encourage students to represent imago-content of their personality, first of all, in the activity free of any frames and limits of educational process. In our opinion, among significant features of such activity should be named practice of making own decisions and problemsolving, especially, when a student is in the independent behavior zone, designing success situations and so on.

Practicability of forming mentioned condition has been proved by social development imperatives. There are no doubts that these imperatives are depicted in state regulatory documents, moreover, these days, according to them in all people's life spheres activity force emphasis is changing the direction from public level to individual one.

Our research has a solid theoretical background. We refer to humanistic pedagogics statements and achievements (I. Bekh, A. Sushchenko), humanistic psychology (B. Bettelheim, C. Rogers). These scientists support ideas of philosophical and ethical humanistic paradigm, highlight top priority of human value (both individual and group levels are taken into consideration), and also give preference to critical thinking and evidence but not fundamentals of religion.

It is necessary to stress out that in our research we consider such statements to be principal: necessity to organize in educational process the conditions for personality to perform one's potential (C. Rogers), and also awareness that "area of independent behavior" is highly effective for personality forming (B. Bettelheim).

We believe that due to this condition student is able to self-determine, cope and successfully overcome certain challenges in education and everyday life, has "success situations" experience with the following community recognition of the success.

One of the most factors in this case is fulfillment of the educational process with minor initiations. The meaning of the term is range of means which define transfer of the personality to the new stage of development in framework of professional physical education teachers' community.

To provide this condition we need to engage students to various volunteer projects or voluntary participation in different public events. Also, to provide this condition we suggest creating and implementation student's score system, where their achievements and performance level in extracurricular activity can be evaluated.

We consider that forming this condition will enable to eliminate contradictions between employers' expectations about ability of physical education teachers to express pedagogical position and the facts of study at physical education department, that in their turn are not always suitable for performing independent position, voluntary participation, freedom to choose forms and ways of self-fulfillment.

The fifth pedagogical condition of forming professional subjectivity of future physical education teachers is implementation of check-out methodology focused on evaluation of the mentioned professional feature of future physical education teachers.

Providing this condition we develop and comprehensively use educational tools to define level of professional subjectivity of students, specialty 014 Secondary Education (Physical Education).

In our opinion, which we represent in this research, it is worthwhile to evaluate professional knowledge, psychological and professional features of future teachers with emphasis on their subjectivity, because current ways of students' educational achievements diagnostics (tests, control assessment materials, qualifying research projects, surveys and questionnaires etc.) are not able to define students' subjectivity level. 
Moreover, we are convinced that design and development of such educational tools will be useful not only for teachers, but for students as well. We mean that results of the evaluation will enable students to acknowledge one's expectations about future professional activity prospects; give them the opportunity to find out their strengths and weaknesses; define promising ways of their abilities development.

Background ideas for the developing the system of evaluation of future physical education teachers' professional subjectivity we find in scientific researches focused on tests theory, also development of empirical research in sociology, pedagogics and psychology.

Having done analysis of a range theoretical and practical scientific researches, we suggest own methodology of future physical education teachers' subjectivity evaluation. There are some essential points of the methodology such as:

- Diagnostics of subjectivity level. This procedure is conducted due to surveys and questionnaires with ranked questions, which were designed according to peculiarities of future physical education teachers' professional activity (we believe that this evaluating procedure is better to hold during job training, 8 semester);

- Expert evaluation of education and quasi-professional activity of students, specialty 014 Secondary Education (Physical Education) in the framework of professional subjectivity performance.

According to our expectations, implementation of check-out methodology focused on evaluation of professional subjectivity level will enable to eliminate contradictions between necessity of complex evaluation of future physical education teachers' professional subjectivity level and shortage of diagnostic tools, which are suitable for peculiarities of educational process for students, specialty 014 Secondary Education (Physical Education).

\section{CONCLuSion}

Therefore, forming professional subjectivity of future physical education teachers will be efficient due to these pedagogical conditions:

- updating the provided subjects' content with thematic modules focused on professional subjectivity forming;

- creating positive image of professional prospects during foreign study course;

- reflective ambience forming for awareness of the contradiction between preferable and current status of professional competencies development;

- encouraging students to represent their personality in extracurricular socially significant activity;

- implementation of check-out methodology focused on evaluation of professional subjectivity level of future physical education teachers;

- Next steps of our research will be focused on designing and developing the model of forming professional subjectivity of future physical education teacher. Also we consider scientific project of the mentioned model verification to be top-priority research trend in future.

\section{REFERENCES}

[1] Burenko M. S. (2012) Formuvannia fakhovykh kompetentsii maibutnikh treneriv-vykladachiv u protsesi vyvchennia tsyklu profesiino-oriientovanykh dystsyplin [Formation of professional competences of future coaches of children in the process of studying the cycle of professionally oriented disciplines subjects]. Dissertation for the degree of a candidate of pedagogical sciences ( PhD) in specialty 13.00 .04 «Theory and methodology of vocational education». Classic Private University Zaporizhzhia, 224 [in Ukrainian].

[2] Verbytskyi A. A. (1987) Kontseptsyia znakovo-kontekstnoho obuchenyia v vuze [The concept of signcontextual education in high school] Voprosy psykholohyy 5, 31-39 [in Russian].

[3] Hordiichuk Ye. S. (2013) Osoblyvosti otrymannia podviinykh dyplomiv [Features of obtaining dual degree] Naukovyi visnyk Natsionalnoho universytetu bioresursiv i pryrodokorystuvannia Ukrainy. Seriia : 
Pedahohika, psykholohiia, filosofiia. 192, 116-120. Retrieved from http://nbuv.gov.ua/UJRN/nvnau_ ped_ 2013_192(1)__20 [in Ukrainian].

[4] Zdanevych L. ( 2015) Realizatsiia kompetentnisnoho pidkhodu yak odnoho z instrumentiv profesiinoi pidhotovky maibutnikh fakhivtsiv u vyshchomu navchalnomu zakladi [Realization of the competence approach as one of the tools of professional training of future specialists in higher educational institutions] Pedahohichnyi dyskurs. 18, 90-96. Retrieved from http://nbuv.gov.ua/UJRN/0peddysk_2015_18_19 [in Ukrainian].

[5] Panok V., Tytarenko T., Chepelieva N. (1999) Osnovy praktychnoi psykholohii [ Fundamentals of practical psychology: coursebook] Kyiv : Lybid, 536 [in Ukrainian].

[6] Rubynshtein S. L. (2003) Bytye y soznanye [Being and consciousness] Chelovek y myr SPb, 590 [in Russian].

[7] Riabchenko L. O. (2011) Upravlinnia samostiinoiu piznavalnoiu diialnistiu vchyteliv zahalnoosvitnikh zakladiv [ Management of independent cognitive activity of teachers of general educational institutions]. Dissertation for the degree of a candidate of pedagogical sciences (PhD) in specialty 13.00.04 «Theory and methodology of vocational education». Classic Private University Zaporizhzhia, 220 [in Ukrainian].

[8] Chornoshtan A.H. (2002) Profesiina pidhotovka maibutnoho vchytelia fizychnoho vykhovannia na osnovi modulno-reitynhovoi tekhnolohii navchannia [Professional training of the future teacher of physical education on the basis of modular-rating technology of training] Dissertation for the degree of a candidate of pedagogical sciences (PhD) in specialty 13.00.04 «Theory and methodology of vocational education». Luhansk Taras Shevchenko National Univercity, 264 [in Ukrainian].

Citation: Bytsiuk Viktoriia, Mazin Vasy. "Pedagogical Conditions for Forming Professional Subjectivity of Future Physical Education Teachers". International Journal of Humanities Social Sciences and Education (IJHSSE), vol. 6, no.7, 2019, pp. 7-13. doi: http://dx.doi.org/ 10.20431/2349-0381.0607002.

Copyright: (c) 2019 Authors. This is an open-access article distributed under the terms of the Creative Commons Attribution License, which permits unrestricted use, distribution, and reproduction in any medium, provided the original author and source are credited. 